\title{
Structural Equation Modeling (SEM) Analysis with Warppls Approach Based on Theory of Planned Behavior (TPB)
}

\author{
Ni Wayan Surya Wardhani,Waego Hadi Nugroho", Adji Achmad Rinaldo Fernandes, Solimun \\ Department of Statistics, Faculty of Mathematics and Natural Sciences, Brawijaya University, Indonesia
}

Received October 30, 2019; Revised May 3, 2020; Accepted May 23, 2020

Copyright $(2020$ by authors, all rights reserved. Authors agree that this article remains permanently open access under the terms of the Creative Commons Attribution License 4.0 International License

\begin{abstract}
WANT-E is a tool created to purify methane gas from organic waste intended as a substitute for renewable gas fuel. The WANT-E product is new because it is necessary to do research related to the public interest in WANT-E products. This study uses primary data obtained from questionnaires with variables based on Theory of Planned Behavior (TPB), namely behavior attitudes, subjective norms, perceived behavior control, and behavior interests that are spread to the community of Cibeber Village, Cikalong Subdistrict, Tasikmalaya Regency that uses LPG gas cylinders or stove using sampling techniques in the form of the judgment sampling method. The analysis used is SEM with the WarpPLS approach, which is to determine the effect of relationships between variables. The results of the analysis obtained the effect of a positive relationship between behavior attitudes variables on subjective norms, behavior attitudes toward perceived behavior control, subjective norms of behavior interests, and perceived behavior control of behavior interests. Then the influence of indirect relations on subjective norms and perceived behavior control was obtained as mediation between behavior attitudes toward behavior interests.
\end{abstract}

Keywords SEM WarpPLS, Behavior Attitudes, Subjective Norms, Perceived Behavior Control, Behavior Interests

\section{Introduction}

Structural Equation Modeling (SEM) is an analysis conducted to obtain data and relationships between latent variables that are conducted simultaneously (Solimun et al., 2017). PLS is a more complex method than SEM because it can be applied to both the reflective indicator model and the formative indicator model (Fernandes et al., 2020). The WarpPLS method is the development of PLS analysis which can identify and predict linear or nonlinear relationships between latent variables (Fernandes et al., 2019).

Tasikmalaya Regency, precisely in Kampung Cibeber, Cibeber Village, Cikalong Subdistrict is one area that does not yet have a landfill (TPA). Therefore, we need a solution for handling waste so as not to continue to increase air pollution. WANT-E is a tool created to purify methane gas from organic waste intended as a substitute for renewable gas fuels. However, this tool is a product of new findings and is not yet known by the public, thus, it is necessary to do a study related to the public interest in WANT-E products.

Theory of Planned Behavior (TPB) is designed to predict and explain human behavior in certain contexts (Ajzen, 1991). This theory consists of several variables, namely behavior, and attitudes, subjective norms, perceived behavioral control that can influence behavioral intentions or interests to do something.

Referring to research Setyawan (2016), the application of SEM-PLS analysis was done to find out the factors that influence the intention to reuse information-based mobile application. Then, research Rahmah (2011), explained about the use of variables based on TPB to determine the effect of behavior and attitudes, subjective norms, and perceived behavioral control on the intention to buy illegal college textbooks on students. On that account, the application of SEM analysis with the WarpPLS approach in this study was used to determine the effect of variables based on TPB on people's interest in WANT-E products. Thus, this study is expected to be able to know the interest of the people of Kampung Cibeber, Cibeber Village, Cikalong Subdistrict, Tasikmalaya Regency on WANT-E products. 


\section{Materials and Methods}

\subsection{Structural Equation Modelling (SEM)}

Structural Equation Modeling (SEM) is a multivariate analysis that combines aspects of a simultaneous equation system, path analysis, or regression analysis with factor analysis. The approach to SEM analysis is divided into two types, namely covariance-based and variance-based. The use of covariance-based SEM is influenced by several assumptions including multivariate normal distribution and large sample size. Besides, to test and predict the coefficients of structural models to obtain causal relationships between latent variables, the indicators used must be reflective. On the other hand, the use of variance-based SEM can be used without requiring the assumption of normality. Variance-based SEM analysis includes Generalized Structured Component Analysis (GSCA), Partial Least Square (PLS), and WarpPLS.

\subsection{SEM with WarpPLS Approach}

WarpPLS Analysis is a development of the Partial Least Square (PLS) analysis developed by Ned Kock in the form of a computer program package (Solimun et al., 2017). Partial Least Square Analysis (PLS) was first developed by Herman Wold (a teacher of Karl Joreskog who developed SEM) with the aim as an alternative to situations when the theoretical basis for designing a model is weak or has not been found or some indicators do not meet the reflective measurement model, and consequently, it is formative (Solimun et al., 2017). Partial least square (PLS) is an integrated analysis technique between confirmatory factor analysis, principal component analysis, path analysis, and structural models. SEM-PLS is a causal modeling approach that aims to maximize the variance of latent response variables that can be explained by latent predictor variables (Sholihin and Ratmono, 2013). According to Biske et al. in Sholihin and Ratmono (2013), the problem of measuring latent variables is still a major debate in research, especially social research with issues regarding indicators that are the cause of the measured latent variables. Thus, the existence of PLS is beneficial because it can analyze the reflective and formative measurement models and latent variables without causing problems with identification with one indicator (Fernandes et al., 2020). An overview of the reflective and formative indicator models by Sholihin and Ratmono (2013) can be seen in Figure 1.

The PLS approach is distribution free, that is, it does not assume certain distributed data. WarpPLS is a development of PLS, accordingly, the properties that apply to PLS also apply to WarpPLS (Solimun et al., 2017). That being so, WarpPLS can be used as a confirmation of the theory (hypothesis testing) and also build models that do not yet have a theoretical basis or hypotheses testing (Hidayat et al., 2019). WarpPLS can also be used for non-recursive models and is equipped with an analysis of nonlinear models.
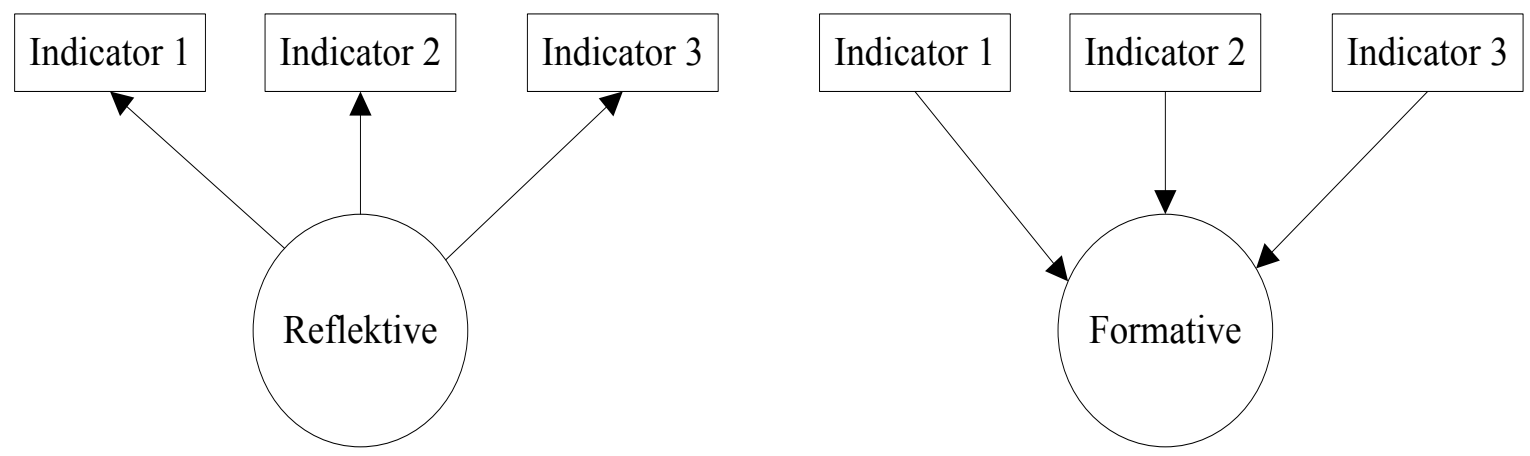

Figure 1. Reflective and Formative Indicator Models 


\subsection{Stages of SEM Analysis with WarpPLS}

SEM analysis using the WarpPLS approach consists of several stages. According to Solimun et al (2017), structural equation modeling (SEM) with the WarpPLS approach consists of seven stages. The following are the stages of SEM analysis using the WarpPLS approach.

1. Designing a Structural Model (Inner Model)

2. Designing a Measurement Model (Outer Model)

3. Constructing the Path Diagram

4. Converting Path Diagram to Equation System

5. Estimating the Parameter

6. Evaluating the Goodness of Fit

7. Testing the Hypotheses

\subsection{Bootstrap Resampling Method}

The resampling method used in this study was the bootstrap resampling method (Şahinler and Topuz, 2007). Bootstrap resampling method is a resampling method that aims to determine the estimation of standard errors and confidence intervals of population parameters such as mean, ratio, median, proportion, correlation coefficient, or regression coefficient without using distribution assumptions (Tibshirani and Efron, 1993). The principle of the bootstrap method is to estimate the parameters in each bootstrap resampling data in the form of a random sample taken from the original data sample (Ariani et al., 2017). Sampling using the bootstrap method is done by taking a number of samples that are not more than the original number of samples (Solimun et al., 2017).

Of the several resampling methods available in SEM analysis using the WarpPLS approach (Solimun, 2020), the bootstrap resampling method was chosen because it is more effective than the other methods. This is supported by research by Iskandar et al. (2013) which stated that the bootstrap resampling method is more effective than the Jackknife resampling method. In addition, this method is more easily understood by the number of repetitions of the sample to achieve convergence that has been determined one hundred times.

The following are the steps in the bootstrap method for estimating standard errors (Tibshirani and Efron, 1993).

1) Determining the number of $B$ times in the bootstrap sample $\left(x_{1}^{*}, x_{2}^{*}, \ldots, x_{B}^{*}\right)$ obtained from a random collection of $\mathrm{n}$ elements from the original data sample $\left(x_{1}, x_{2}, \ldots, x_{n}\right)$.

2) Calculating bootstrap replication for each bootstrap sample.

3) Conducting a bootstrap estimation approach for averages.

4) Estimating the standard error using the standard deviation for bootstrap that is replicated B times with the following formula.

\subsection{Variables and Variable Measurements}

Variables are characteristics, properties, or attributes of a research object that are relevant to the problem to be measured and must have a value that varies between objects (Hidayat et al., 2019). According to Solimun (2010), based on the measurement process, the variables are divided into two types, namely manifest variables and latent variables. Manifest variables are variables that can be measured directly (observable), while latent variables are variables that cannot be measured directly (unobservable). Measurements for latent variables are carried out using instruments in the form of questionnaires that produce data from each indicator or item. The measurement method can be done by 5 methods as follows.

1) Total Score Method

The total score method is a variable measurement method by using the sum of all indicators in order to obtain total score data in the form of latent variable data.

2) Average Score Method

The average score method is a variable measurement method by using the average score of all indicators so that the average score of data is in the form of latent variable data.

3) Rescoring Method

The rescoring method is a method of measuring variables by changing the total score to the initial scale and calculation of latent variable data.

4) Factor Score Method

The factor score method is the variable measurement method used when the weights of each indicator are different. The latent variable in factor analysis is a reflection of a number of indicators, accordingly, it is called as the reflective form.

5) Main Component Score Method

The principal component score method is the variable measurement method used when the weights of each indicator are different. The latent variable in the analysis of the main components is formed from a number of indicators, accordingly, it is called as the formative forms.

\subsection{Measurement Scale for Research Instruments}

According to Riduwan (2005), the measurement scale is used to classify the variables to be measured so that there are no errors in determining data analysis and subsequent research steps. In general, the type of measurement scale is divided into four, including a nominal scale, ordinal scale, interval scale, and ratio scale. In addition to the four types of measurement scales, there are special measurement scales to measure behavior and personality, one of which is the attitude scale. The attitude scale uses research instruments with the following forms of measurement. 
1) Likert Scale

Likert Scale is a scale used to measure the attitudes, opinions, and perceptions of a person or group of social phenomena. There is a range of attitudes of a person on this scale, for example strongly agree to disagree.

2) Guttman Scale

The Guttman scale is a scale used to measure the dimensions of a variable that is clear, explicit, and consistent. The data generated is dichotomous data, for example, agree or disagree.

3) Semantic Differential Scale

Semantic Differential Scale is a scale used to measure attitudes with respondents being asked directly to give weight assessment of a stimulus in a continuous line with a very positive answer to the right and vice versa.

4) Staple Scale

The staple scale is a scale used to measure attitudes with a scale given a negative and positive value.

5) Thurstone Scale

Thurstone scale is a scale used to ask respondents to choose an agreed statement from several statements that present different data. Each item has a weight and when sorted produces values that are the same distance.

\subsection{Summated Rating Scale (SRS) Scaling}

The scaling of a Likert scale type instrument is performed by the summated rating scale (SRS) method. In SRS scaling, each response to an item is scored with the assumption of a normal distribution, this is done so that each score can be compared. The SRS method is carried out by confirming the questionnaire score data with the $\mathrm{Z}$ score using the normal distribution. The results of the SRS scaling process make the distance between scores have the same units and the data obtained becomes interval data. According to Setiawati et al. (2013), the SRS scaling calculation process is carried out with the help of the Microsoft Excel program with the following steps.

1) Counting the number of subject response frequency per item.

2) Changing the frequency score into a proportion score, cumulative proportion, and calculating the proportion score by dividing the frequency by the number of respondents.
3) Calculating the cumulative proportion by adding the proportion in each category to the proportion of the previous category.

4) Calculating the median cumulative proportion of half the proportion in the category added by the cumulative proportion of the previous category.

5) Calculating the critical value of $Z$ from the median of cumulative proportions.

6) Adding the lowest score with a value so that it becomes zero. Then the value is added to all critical values of $Z$ so that a positive value scale is obtained.

\subsection{Product Overview}

WANT-E (Waste Gas to Be Renewable Energy for Sustainable Environment) is a tool created to purify methane gas from gases that result from an anaerobic fermentation process from organic waste. Anaerobic fermentation is a method used by cells to extract energy from carbohydrates when oxygen or other electron acceptors are not available in the surrounding environment. The results obtained from purification are intended to make methane gas instead of renewable gas fuels.

Purification that occurs is carried out by adsorbents arranged in the product structure. Adsorbents are solid substances that are specific and are made of porous materials that can absorb a particle (Saragih, 2008). The adsorbent used has no use limit so it can be used forever, but treatment needs to be done one to two months after use. The treatment is done by soaking with an activator in the form of an acidic substance for \pm 24 hours.

WANT-E products are composed of five parts that have their own roles in the purification process that occur, as follows:

1) Organic waste bin

2) Adsorbent I (Activated Carbon, Calcium Monoxide (Cao), Potassium Hydroxide ( $\mathrm{KOH})$ which functions to absorb carbon dioxide $\left(\mathrm{CO}_{2}\right)$ and hydrogen sulfide $\left(\mathrm{H}_{2} \mathrm{~S}\right)$.

3) Adsorbent II (Silica Gel and Zeolite) which functions to absorb carbon dioxide $\left(\mathrm{CO}_{2}\right)$, hydrogen sulfide $\left(\mathrm{H}_{2} \mathrm{~S}\right)$, and water vapor $\left(\mathrm{H}_{2} \mathrm{O}\right)$.

4) Adsorbent III (ferric hydroxide $\left(\mathrm{Fe}(\mathrm{OH})_{3}\right)$ which functions to absorb hydrogen sulfide $\left(\mathrm{H}_{2} \mathrm{~S}\right)$ and reduce odor.

5) Methane gas reservoirs. 


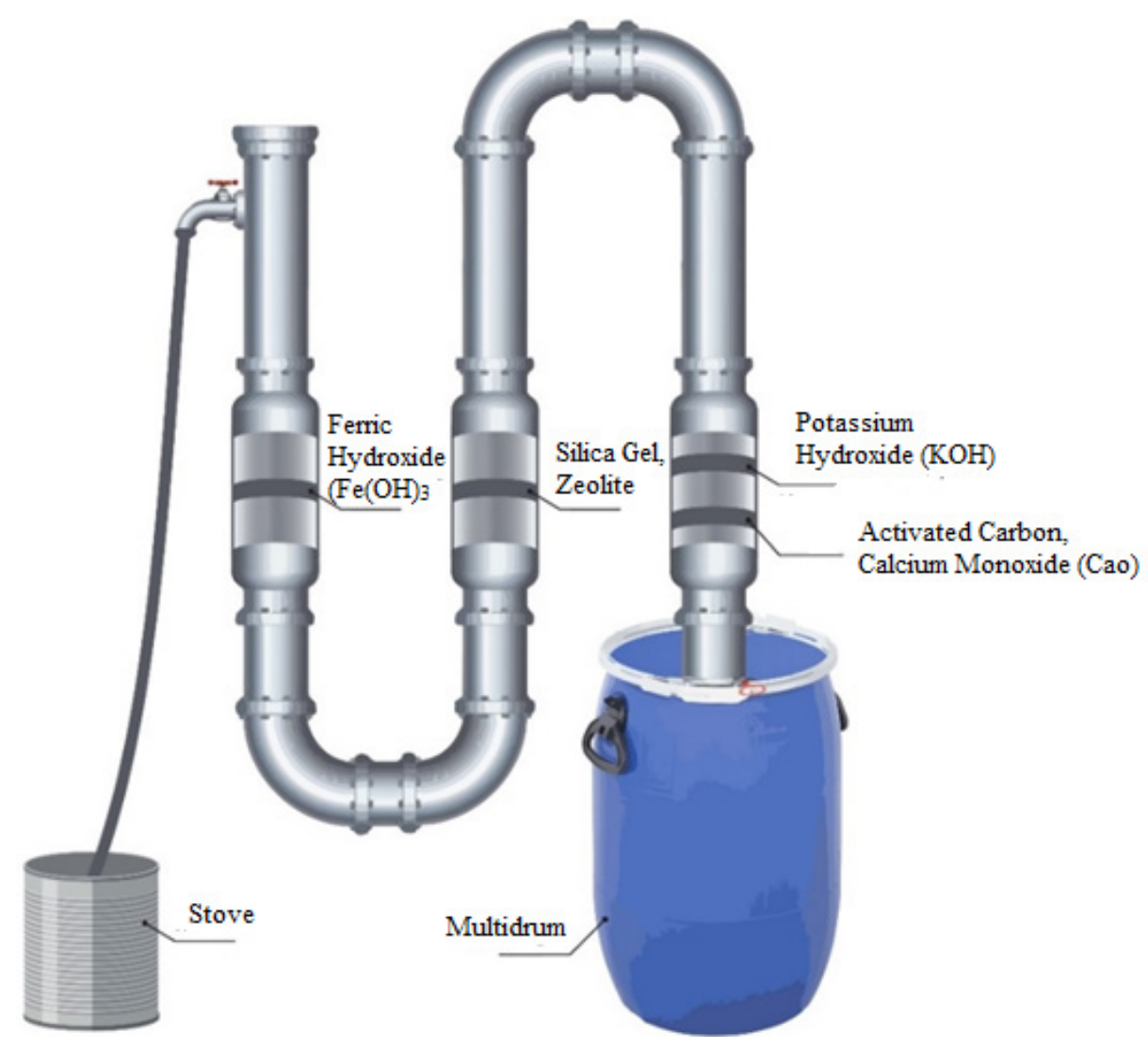

Figure 2. WANT-E products

The description of WANT-E products is presented in Figure 2. Based on the constituent parts of WANT-E products in Figure 2, the procedure of WANT-E products is as follows.

1) Inserting organic waste into multidrum.

2) Covering the multidrum and giving holes to install the WANT-E pipe.

3) Letting the adsorbent work according to its function for 1 to 2 days.

4) Methane gas is ready to use.

5) Turning the faucet slowly and turning on the stove with fire to use methane gas (the amount of fire can be adjusted by how much the faucet is open).

6) Simply turning the faucet in the opposite direction to turn off the fire on the stove.

In the use of WANT-E products, there are several advantages, as follows.

1) As a substitute for natural gas.

2) It's easier to renew gas fuel.

3) Expense is more efficient.

4) The risk of environmental pollution can be reduced.

5) There is no risk in its use such as explosive gas.

\subsection{Theory of Planned Behavior (TPB)}

Theory of Planned Behavior (TPB) was developed by Icek Ajzen in 1991 for the development of the Theory of Reasoned Action (TRA). Theory of Planned Behavior (TPB) is a theory that predicts consideration of behavior because individuals have the intention to do so. Theory of Planned Behavior (TPB) is designed to predict and explain human behavior in certain contexts (Ajzen, 1991). 


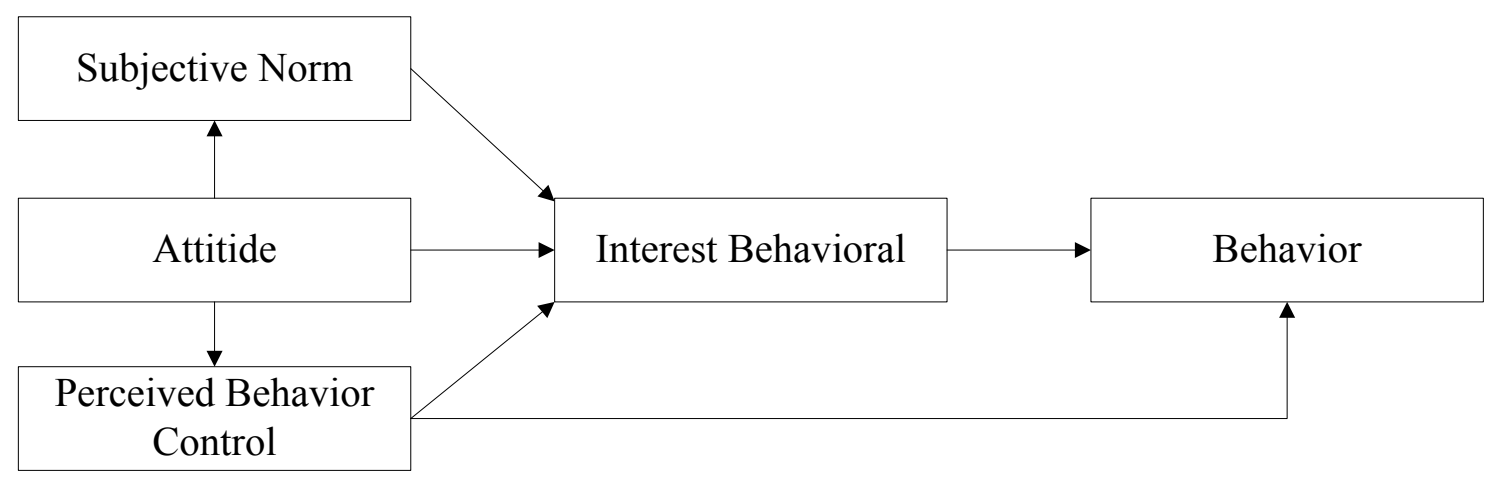

Figure 3. The framework of Theory of Planned Behavior (TPB)

Theory of Planned Behavior (TPB) has advantages over theories about other individual behaviors, this is because TPB can identify a person's belief in control of something that will occur from the results of the behavior, thus differentiating between one's desires and unwilling behavior (Pratiwi, 2017). As already explained before, TPB is a development of TRA, wherein TRA, behavioral interest is predicted by attitudes and subjective norms. Then the TPB added a construct that did not yet exist, namely perceived behavioral control (Hartono, 2007). The following is a framework of the TPB model presented in Figure 3. The three constructs explained in Figure 3. are as follows.

1) Behavior and attitudes

Attitudes and personality traits are usually performed to predict behavior (Ajzen, 1991). Attitude is a favorable evaluative reaction to something or several things, shown in beliefs and feelings of behavior (Rahmah, 2011). Another definition of attitude according to Eagly and Chaiken in (Rahmah, 2011) is the tendency of someone who is expressed by evaluating unity with some degree to support or not to support. The attitude is concluded from various observations on the object expressed in the form of cognitive, affective (emotional), and behavioral responses (Rahmah, 2011). Based on these definitions, it shows that attitude consists of cognitive components, affective components (emotions), and beliefs (Rahmah, 2011).

2) Subjective Norms

According to Fishbein and Ajzen (1975), subjective norms are one's beliefs about the expectations of people who influence individuals or groups to display certain behaviors or not. Then according to Hogg and Vaughan (Rahmah, 2011), they argued that subjective norms are the product of one's perception of beliefs that others have. Subjective norms generally consist of two components, namely normative beliefs and motivation to comply. Normative beliefs are beliefs about other people's expectations of him/her that becomes a reference to display behavior or not, while motivation to comply is the motivation to meet these expectations.

3) Perceived Behavior Control

According to Fishbein and Ajzen (1975), perceived behavior control is one of the determinants in behavior. Behavioral control can be said as an individual's belief about the factors that can facilitate or hinder the behavior (control belief) and the perceived strength of these factors (perceived power) (Hartono, 2007).

\subsection{Research Method}

1) Model Design Based on Theory

In the path analysis model in SEM WarpPLS had two relationships, namely the inner model and the outer model (Solimun et al., 2017). The design of the inner model of the relationship between latent variables was based on the research hypothesis. The relationship between latent variables could be a proposition that could be used in exploratory relationship analysis. On the other hand, the outer model was a specification of the relationship between latent variables with indicators that were reflective or formative. If the measurement model selection was not correct, the wrong analysis results would be obtained.

\section{2) Path Diagram Construction}

The results of the structural model (inner model) and measurement model (outer model) would be more easily understood if constructed or expressed in the form of a path diagram. The use of WarpPLS notation in the path diagram was the same as PLS notation.

3) Model Identification

\section{a) Inner Model}

The inner model was a specification of the relationship between latent variables based on the theory of substantive research. Latent variables and indicators could be standardized without losing their general properties so that constant parameters could be removed from the model. The inner equation can be written as in equation (1).

$$
\mathbf{Y}=\boldsymbol{\beta} \mathbf{Y}+\boldsymbol{\gamma} \mathbf{X}+\mathbf{e}
$$

Description:

Y: vector of endogenous latent variables $(\mathrm{m} \times \mathrm{l})$

$\mathbf{X}$ : vector of exogenous latent variables $(\mathrm{n} \times \mathrm{l})$

e: error vector inner model $(\mathrm{m} \times 1)$

$\boldsymbol{\beta}$ : path coefficient matrix between endogenous 
variables $(\mathrm{m} \times \mathrm{m})$

$\gamma$ : matrix of exogenous variable path coefficients to endogenous $(\mathrm{m} \times \mathrm{n})$

\section{b) Outer Model}

The outer model was a specification of the relationship between latent variables and indicators. There were two models of indicators on the outer model including the reflective and formative indicator models (Solimun, 2010). In the reflective indicator model, there were two models namely in equations (2) and (3).

$$
\begin{aligned}
& x=\lambda_{X} X+u \\
& y=\lambda_{Y} Y+v
\end{aligned}
$$

Description:

$\mathbf{X}$ : exogenous latent variable

Y: endogenous latent variable

$\mathbf{x}$ : an indicator for exogenous variables

$\mathbf{y}$ : an indicator for endogenous variables

$\lambda_{\mathrm{X}}$ : loading matrix for exogenous latent variables

$\lambda_{Y}$ : loading matrix for endogenous latent variables

$\mathbf{u}$ : error for exogenous latent variables

$v$ : error for endogenous latent variables

4) Parameter Estimation

Parameter estimation in WarpPLS was the same as PLS using the least square. Parameter estimation was done by an iteration calculation process that would stop if a convergent condition has been reached. The calculation process was done by three-stage iteration. The first stage produced a stable weight estimator by calculating the outside approximation and inside approximation of the latent variable. The estimator to get outside approximation was the inner model estimator and the estimator to get inside approximation was the outer model estimator. The second step was to predict the relationship between the path and Ordinary Least Square (OLS). The third stage calculated the mean of each indicator with the original data and the weights obtained from stage one.

There are 4 steps in estimating the first stage parameters, namely:

Step 1: Estimating the value of latent variables

$$
\hat{\mathrm{Y}}_{\mathrm{j}}=\sum_{\mathrm{k}} \tilde{\mathrm{W}}_{\mathrm{jk}} \mathrm{x}_{\mathrm{jk}}
$$

Step 2: Outside approximation

$$
\begin{gathered}
\hat{\mathrm{Y}}_{\mathrm{j}}= \pm f_{j} \sum_{\mathrm{k}} \mathrm{w}_{\mathrm{jk}} \mathrm{x}_{\mathrm{jk}} \\
\hat{Y}_{j}=\operatorname{sign}\left[\operatorname{sign}\left\{\operatorname{cor}\left(x_{j k}, Y_{j}\right)\right\}\right]
\end{gathered}
$$

Step 3: Inside approximation

$$
\mathrm{Z}_{\mathrm{j}}=\sum_{\mathrm{i}} \mathrm{V}_{\mathrm{ji}} \hat{\mathrm{Y}}_{\mathrm{i}}
$$

Where:

$$
v_{j k}=\left\{\begin{array}{l}
\operatorname{sign} \operatorname{cor}\left(\hat{Y}_{j} ; \hat{Y}_{i}\right) \\
0
\end{array}\right.
$$

Step 4: Update the Outer weight

$$
\mathrm{X}_{\mathrm{jk}}=w_{\mathrm{jk}} \mathrm{Z}_{\mathrm{j}}
$$

Where: $w_{j k}=\left(Z_{j}^{\prime} Z_{j}\right)^{-1} Z^{\prime}{ }_{j} x_{j k}=\operatorname{cor}\left(\mathrm{x}_{\mathrm{jk}}, Z_{\mathrm{j}}\right)$

Description:

Yi: latent variable outside approximation

$\mathrm{Zj}$ : latent variable inside approximation

jk: manifest variable

$\mathrm{v}$ : inner weight

w: weight coefficient

$\mathrm{j}: 1,2,3, \ldots, \mathrm{J}$ for many latent variables

i: $1,2,3, \ldots$, I for many neighboring latent variables

$\mathrm{jk}: 1,2,3, \ldots, \mathrm{K}$ for many relations of the manifest variable without $\mathrm{j}$

After the score of the latent variable is estimated in stage one, the second step is estimating the relationship of the path with ordinary least square.

$$
\hat{Y}_{j}=\sum_{i \leftrightarrow j} \hat{\beta}_{j i} Y_{i}
$$

Where:

$$
\hat{\beta}_{j i}=\left(Y_{i}^{\prime} Y_{i}\right)^{-1} Y_{i}^{\prime} Y_{j}
$$

In the third stage, the estimation for the coefficient on the outer model is carried out. For the reflective indicator model, an estimation can be carried out as follows:

$$
\mathrm{x}_{\mathrm{ij}}=\hat{\lambda}_{\mathrm{jk}} \mathrm{Y}_{\mathrm{j}}
$$

Where:

$$
\hat{\lambda}_{j k}=\left(Y_{j}^{\prime} Y_{j}\right)^{-1} Y_{j}^{\prime} x_{j k}
$$

Estimation of the formative indicator model can be done as follows:

$$
\mathrm{Y}_{\mathrm{j}}=\sum_{\mathrm{k}} \hat{\pi}_{\mathrm{jk}} \mathrm{x}_{\mathrm{jk}}
$$

Where:

$$
\hat{\pi}_{\mathrm{jk}}=\left(\mathrm{X}_{\mathrm{j}}^{\prime} \mathrm{X}_{\mathrm{j}}\right)^{-1} \mathrm{X}_{\mathrm{j}}^{\prime} \mathrm{Y}_{\mathrm{j}}
$$

5) Model Evaluation

The basis for evaluating the PLS model was the nonparametric prediction measurement. There were 2 evaluation models as follows. 
a) Inner Model

Evaluation of the inner model was done by using the Goodness of Fit criteria, which was an index and measure of the goodness of relationships between latent variables (inner model). The goodness of Fit in the WarpPLS analysis was the Model Fit and Quality Indices (Solimun et al., 2017). The criteria used were rule of thumb, i.e. if there were one or two indicators not met, then the model could still be used.

\section{b) Outer Model}

Evaluation of the outer model regarding the validity test and reliability checking of research instruments. Testing the validity of the questionnaire in WarpPLS was evaluated by convergent validity test, discriminant validity of each indicator, and discriminant validity for the questionnaire. On the other hand, the reliability check could be evaluated by Cronbach's composite reliability and alpha tests (Solimun et al., 2017).

\section{6) Hypothesis Testing}

Parameter hypothesis testing was done by the resampling method and t-test. The resampling method used was bootstrap resampling, while the t-test used was based on the test statistics in equation (11).

$$
t=\frac{\hat{\theta}-\theta}{s / \sqrt{n}}
$$

a) Hypothesis for the outer model

$$
H_{0}: \lambda_{i}=0 \quad \text { vs } \quad H_{1}: \lambda_{i} \neq 0
$$

Test Statistic:

$$
t=\frac{\hat{\lambda}}{S E(\hat{\lambda})}
$$

Description :

$\lambda \quad$ : path coefficient of the load factor $S E(\lambda):$ standard error of $\lambda$ the coefficient

b) Hypothesis for the inner model (exogenous)

The effect of exogenous latent variables on endogenous variables.

$$
H_{0}: \gamma_{i}=0 \quad \text { vs } \quad H_{1}: \gamma_{i} \neq 0
$$

Test Statistic :

$$
t=\frac{\hat{\gamma}}{S E(\hat{\gamma})}
$$

Description:

$\gamma \quad$ : path coefficient of the effect of exogenous variables on endogenous variables

$S E(\gamma)$ : standard error of $\gamma$ coefficient.

c) Hypothesis for the inner model (endogenous)

The effect of endogenous latent variables on endogenous variables.

$$
H_{0}: \beta_{i}=0 \quad \text { vs } \quad H_{1}: \beta_{i} \neq 0
$$

Test Statistic:

$$
t=\frac{\hat{\beta}}{S E(\hat{\beta})}
$$

Description:

$\beta \quad$ : path coefficient of the effect of endogenous variables on endogenous variables.

$S E(\beta)$ : standard error of $\beta$ coefficient.

\section{Results and Discussion}

To find out the distribution of respondents' scores and the average value, it can be done by using a frequency distribution. A frequency distribution is also used to determine the value of the indicator or variable in question. The results of the descriptive analysis of variables based on the frequency of respondents' answers are presented in Table 1.

According to Solimun et al. (2017), the criteria that can be used to measure variables in the form of a low-high or bad continuum are as follows.

$$
\begin{array}{ll}
1-1.5 & =\text { Very Low/Very Bad } \\
1.5>-2.5 & =\text { Low/Bad } \\
2.5>-3.5 & =\text { Medium } \\
3.5>-4.5 & =\text { High/Good } \\
4.5> & =\text { Very High/Very Good }
\end{array}
$$

\begin{tabular}{|c|c|c|c|}
\hline \multirow{2}{*}{ Variable } & \multirow{2}{*}{ Indicator } & \multicolumn{2}{|c|}{ Mean } \\
\hline & & Indicator & Variable \\
\hline \multirow{3}{*}{ Attitude $\left(\mathrm{X}_{1}\right)$} & $\begin{array}{c}\text { Cognitive Beliefs } \\
\left(\mathrm{X}_{1.1}\right)\end{array}$ & 4.31 & \multirow{3}{*}{4.25} \\
\hline & $\begin{array}{c}\text { Affective } \\
\text { Confidence }\left(\mathrm{X}_{1.2}\right)\end{array}$ & 4.37 & \\
\hline & $\begin{array}{c}\text { Behavioral Belief } \\
\left(\mathrm{X}_{1.3}\right)\end{array}$ & 4.14 & \\
\hline \multirow{2}{*}{$\begin{array}{c}\text { Subjective } \\
\text { Norm } \\
\left(\mathrm{Y}_{1}\right)\end{array}$} & $\begin{array}{c}\text { Normatives } \\
\text { Beliefs }\left(\mathrm{Y}_{1.1}\right)\end{array}$ & 4.08 & \multirow{2}{*}{4.07} \\
\hline & $\begin{array}{l}\text { Motivation to } \\
\text { Comply }\left(\mathrm{Y}_{1.2}\right)\end{array}$ & 4.01 & \\
\hline \multirow{2}{*}{$\begin{array}{c}\text { Perceived } \\
\text { Behavior } \\
\text { Control } \\
\left(\mathrm{Y}_{2}\right)\end{array}$} & Control Belief $\left(\mathrm{Y}_{2.1}\right)$ & 4.00 & \multirow[b]{2}{*}{4.10} \\
\hline & $\begin{array}{l}\text { Perceived Power } \\
\qquad\left(\mathrm{Y}_{2.2}\right)\end{array}$ & 4.20 & \\
\hline \multirow{3}{*}{$\begin{array}{c}\text { Behavioral } \\
\text { Interest }\left(\mathrm{Y}_{3}\right)\end{array}$} & $\begin{array}{c}\text { Positive Perception } \\
\left(\mathrm{Y}_{3.1}\right)\end{array}$ & 4,39 & \multirow{3}{*}{4.19} \\
\hline & Desire $\left(\mathrm{Y}_{3.2}\right)$ & 4.13 & \\
\hline & $\begin{array}{c}\text { Recommendation } \\
\left(\mathrm{Y}_{3.3}\right)\end{array}$ & 4.11 & \\
\hline
\end{tabular}

Based on these criteria, information can be obtained from the values of the variables listed in Table 1 that behavioral interest, subjective norms, perceived behavioral control, and behavioral interest in WANT-E products was in good condition and all variables' indicators were also in good condition.

Table 1. Descriptive Statistics Analysis Results 
In the estimation of SEM parameters with the WarpPLS approach, there were analytical algorithms, namely the outer model and the inner model algorithms. The algorithm in the inner model can be determined by using a linearity test. The linearity test aimed to determine the relationship between two linear latent variables or insignificant. The linearity test was carried out using the RRT (Ramsey RESET Test) with the results presented in Table 2 .

Table 2. Linearity Test Results

\begin{tabular}{|c|c|c|c|}
\hline \multicolumn{2}{|c|}{ Variable } & p-value & Information \\
\hline 1. & $\begin{array}{c}\text { Attitude }\left(\mathrm{X}_{1}\right) \rightarrow \text { Subjective } \\
\text { Norm }\left(\mathrm{Y}_{1}\right)\end{array}$ & 0.05904 & Significant \\
\hline 2. & $\begin{array}{c}\text { Attitude }\left(\mathrm{X}_{1}\right) \rightarrow \text { Perceived } \\
\text { Behavior Control }\left(\mathrm{Y}_{2}\right)\end{array}$ & 0.03879 & Not Significant \\
\hline 3. & $\begin{array}{c}\text { Attitude }\left(\mathrm{X}_{1}\right) \rightarrow \text { Behavioral } \\
\text { Interest }\left(\mathrm{Y}_{3}\right)\end{array}$ & 0.05838 & Significant \\
\hline 4. & $\begin{array}{c}\text { Subjective Norm }\left(\mathrm{Y}_{1}\right) \rightarrow \\
\text { Behavioral Interest }\left(\mathrm{Y}_{3}\right)\end{array}$ & 0.19694 & Significant \\
\hline 5. & $\begin{array}{c}\text { Perceived Behavior Control } \\
\left(\mathrm{Y}_{2}\right) \rightarrow \text { Behavioral Interest } \\
\left(\mathrm{Y}_{3}\right)\end{array}$ & 0.90261 & Significant \\
\hline
\end{tabular}

Based on Table 2. with a real level $(\alpha)$ of 0.05 , the relationship between variables of behavior and attitudes on subjective norms, behavior and attitudes on behavioral interest, subjective norms on behavioral interest, and perceived behavioral control on behavioral interest with p-values $>0.05$ was stated to be significant, accordingly, it can be concluded that the relationship between these variables was linear. On the other hand, the relationship between the variables of behavior and attitudes on perceived behavioral control with p-values $<0.05$ was stated as insignificant, thus, it can be concluded that the relationship between these variables was not linear. Based on the algorithm in the inner model, if a relationship model between variables did not meet the linear assumptions, the Warp algorithm was used. Therefore, the inner model algorithm used was the Warp algorithm.

Table 3. Model Fit and Quality Indices Results

\begin{tabular}{|c|c|c|}
\hline \multicolumn{2}{|c|}{ Model fit and quality indices } & Criteria Fit \\
\hline 1 & $\begin{array}{c}\text { Average Path coefficient } \\
\text { (APC) }\end{array}$ & Accepted if $\mathrm{p}<0.05$ \\
\hline 2 & Average R-squared (ARS) & Accepted if $\mathrm{p}<0.05$ \\
\hline 3 & Average adjusted $R$-squared & Accepted if $\mathrm{p}<0.05$ \\
\hline 4 & Average block VIF (AVIF) & Accepted if $\leq 5$ \\
\hline 5 & Average full collinearity VIF & Accepted if $\leq 5$ \\
\hline 6 & Tenenhaus GoF (GoF) & $\begin{array}{c}\text { Small }>0.1, \\
\text { Medium }>0.25, \\
\text { Large }>0.36\end{array}$ \\
\hline 7 & Symphson's paradox ratio & Accepted if $\geq 0.7$ \\
\hline 8 & R squared contribution ratio & Accepted if $\geq 0.9$ \\
\hline 9 & Statistical suppression ratio & Accepted if $\geq 0.7$ \\
\hline 10 & $\begin{array}{c}\text { Nonlinear bivariate causality } \\
\text { direction ratio (NLBCDR) }\end{array}$ & Accepted if $\geq 07$ \\
\hline
\end{tabular}

Evaluation of the structural model (inner model) can be done by looking at the value of the Goodness of Fit Model. There were several measures to see the Goodness of Fit model in the WarpPLS analysis. The goodness of Fit Model values can be seen in Table 3. Based on Table 3, it was known that all of the model fit and quality indices criteria were met. Therefore, it can be said that the Goodness of Fit model was fulfilled and the model in this study can be used for hypothesis testing.

Measurement model (outer model) in SEM WarpPLS with reflective indicators can be evaluated using convergent validity, discriminant validity, and composite reliability. The evaluation results of the measurement model (outer model) are as follows.

\section{1) Convergent Validity}

The measurement of convergent validity was carried out based on the loading value for each research indicator. If the minimum loading value was 0.6 , it can be said to meet convergent validity. The results of calculating the loading value of each indicator can be seen in Table 4 . Based on Table 4, it was known that all research indicators had a loading factor value greater than 0.6 and p-value $<0.05$, therefore, it can be said that convergent validity was fulfilled.

Table 4. Loading Factor Value

\begin{tabular}{|c|c|c|c|}
\hline Variable & Indicator & $\begin{array}{l}\text { Loading } \\
\text { Value }\end{array}$ & p-value \\
\hline \multirow{3}{*}{ Attitude $\left(\mathrm{X}_{1}\right)$} & $\begin{array}{c}\text { Cognitive Beliefs } \\
\left(X_{11}\right)\end{array}$ & 0.893 & $<0.001$ \\
\hline & $\begin{array}{c}\text { Affective } \\
\text { Confidence }\left(\mathrm{X}_{1.2}\right)\end{array}$ & 0.900 & $<0.001$ \\
\hline & $\begin{array}{c}\text { Behavioral Belief } \\
\left(\mathrm{X}_{1.3}\right)\end{array}$ & 0.884 & $<0.001$ \\
\hline \multirow{2}{*}{$\begin{array}{l}\text { Subjective Norm } \\
\left(\mathrm{Y}_{1}\right)\end{array}$} & $\begin{array}{l}\text { Normatives } \\
\text { Beliefs }\left(\mathrm{Y}_{1.1}\right)\end{array}$ & 0.908 & $<0.001$ \\
\hline & $\begin{array}{l}\text { Motivation to } \\
\text { Comply }\left(\mathrm{Y}_{1.2}\right)\end{array}$ & 0.908 & $<0.001$ \\
\hline \multirow{2}{*}{$\begin{array}{c}\text { Perceived } \\
\text { Behavior Control } \\
\left(\mathrm{Y}_{2}\right)\end{array}$} & $\begin{array}{c}\text { Control Belief } \\
\left(\mathrm{Y}_{2.1}\right)\end{array}$ & 0.943 & $<0.001$ \\
\hline & $\begin{array}{c}\text { Perceived Power } \\
\left(\mathrm{Y}_{2.2}\right) \\
\end{array}$ & 0.943 & $<0.001$ \\
\hline \multirow{3}{*}{$\begin{array}{l}\text { Behavioral } \\
\text { Interest }\left(\mathrm{Y}_{3}\right)\end{array}$} & $\begin{array}{c}\text { Positive Perception } \\
\left(\mathrm{Y}_{3.1}\right) \\
\end{array}$ & 0.784 & $<0.001$ \\
\hline & Desire $\left(\mathrm{Y}_{3.2}\right)$ & 0.829 & $<0.001$ \\
\hline & $\begin{array}{c}\text { Recommendation } \\
\left(\mathrm{Y}_{3.3}\right)\end{array}$ & 0.864 & $<0.001$ \\
\hline
\end{tabular}

2) Discriminant Validity

The measurement of discriminant validity can be seen from the loading value of an indicator greater than the cross-loading value and the $\sqrt{A V E}$ value. The results of measurements of loading and cross-loading values for each study variable are presented in Table 5. Based on Table 5, it was known that the loading value for each indicator on the variable was greater than the cross-loading value on the other variables, accordingly, it can be said that the discriminant validity was fulfilled. 
Table 5. Loading and Cross Loading Values

\begin{tabular}{|c|c|c|c|c|}
\hline Indicator & $\begin{array}{c}\text { Attitude } \\
\left(\mathbf{X}_{1}\right)\end{array}$ & $\begin{array}{c}\text { Subjective } \\
\text { Norm } \\
\left(\mathbf{Y}_{1}\right) \\
\end{array}$ & $\begin{array}{l}\text { Perceived Behavior Control } \\
\qquad\left(\mathbf{Y}_{2}\right)\end{array}$ & $\begin{array}{c}\text { Behavioral } \\
\text { Interest } \\
\left(\mathbf{Y}_{3}\right) \\
\end{array}$ \\
\hline $\begin{array}{c}\text { Cognitive Beliefs } \\
\left(X_{1.1}\right) \\
\end{array}$ & $(0.893)$ & -0.157 & -0.400 & 0.304 \\
\hline $\begin{array}{c}\text { Affective } \\
\text { Confidence }\left(\mathrm{X}_{1.2}\right) \\
\end{array}$ & $(0.900)$ & -0.335 & 0.187 & -0.096 \\
\hline $\begin{array}{c}\text { Behavioral Belief } \\
\left(\mathbf{X}_{1.3}\right)\end{array}$ & $(0.884)$ & 0.499 & 0.214 & -0.210 \\
\hline $\begin{array}{c}\text { Normative } \\
\text { Beliefs }\left(\mathrm{Y}_{1.1}\right) \\
\end{array}$ & 0.192 & $(0.908)$ & 0.216 & -0.009 \\
\hline $\begin{array}{l}\text { Motivation to } \\
\text { Comply }\left(\mathrm{Y}_{1.2}\right)\end{array}$ & -0.192 & $(0.908)$ & -0.216 & 0.009 \\
\hline Control Belief $\left(\mathrm{Y}_{2.1}\right)$ & -0.223 & 0.179 & $(0.943)$ & $-0,030$ \\
\hline $\begin{array}{c}\text { Perceived Power } \\
\left(\mathbf{Y}_{2.2}\right) \\
\end{array}$ & 0.223 & -0.179 & $(0.943)$ & 0.030 \\
\hline $\begin{array}{c}\text { Positive Perception } \\
\left(\mathrm{Y}_{3.1}\right) \\
\end{array}$ & -0.499 & 0.910 & -0.072 & $(0.784)$ \\
\hline Desire $\left(\mathbf{Y}_{3.2}\right)$ & 0.310 & -0.266 & -0.056 & $(0.829)$ \\
\hline $\begin{array}{c}\text { Recommendation } \\
\left(\mathbf{Y}_{3.3}\right)\end{array}$ & 0.155 & -0.570 & 0.119 & $(0.864)$ \\
\hline
\end{tabular}

Table 6. AVE Root Value

\begin{tabular}{|c|c|c|c|c|}
\hline Variable & $\begin{array}{c}\text { Attitude } \\
\left(\mathbf{X}_{\mathbf{1}}\right)\end{array}$ & $\begin{array}{c}\text { Subjective Norm } \\
\left(\mathbf{Y}_{\mathbf{1}}\right)\end{array}$ & $\begin{array}{c}\text { Subjective Norm } \\
\left(\mathbf{Y}_{\mathbf{2}}\right)\end{array}$ & $\begin{array}{c}\text { Behavioral } \\
\text { Interest }\end{array}$ \\
\hline $\begin{array}{c}\text { Indicator } \\
\text { Attitude }\left(\mathbf{X}_{\mathbf{1}}\right)\end{array}$ & $(0.892)$ & 0.858 & 0.672 & 0.592 \\
\hline $\begin{array}{c}\text { Subjective Norm } \\
\left(\mathbf{Y}_{\mathbf{1}}\right)\end{array}$ & 0.858 & $(0.908)$ & 0.725 & 0.717 \\
\hline $\begin{array}{c}\text { Perceived Behavior } \\
\text { Control } \\
\left(\mathbf{Y}_{\mathbf{2}}\right)\end{array}$ & 0.672 & 0.725 & $(0.943)$ & 0.738 \\
\hline Behavioral Interest $\left(\mathbf{Y}_{\mathbf{3}}\right)$ & 0.592 & 0.717 & 0.738 & $(0.826)$ \\
\hline
\end{tabular}

Then, to see the discriminant validity of all indicators together, it was done by comparing the $\sqrt{A V E}$ value. The results of $\sqrt{A V E}$ the value are resented in Table 6. Based on $\sqrt{A V E}$ the value in Table 6 , it was known that the $\sqrt{A V E}$ value for each variable was greater than the correlation $\sqrt{A V E}$ value with other variables, thus, it can be said that discriminant validity was fulfilled.

\section{3) Composite Reliability}

The composite reliability value for the latent variables of this study can be calculated using equation (2.30). The results of the calculation of the value of composite reliability can be seen in Table 7. Based on Table 7, it was known that all latent variables of the study had a composite reliability value $\geq 0.7$, consequently, it can be concluded that the composite reliability was met.

Table 7. Composite Reliability Value Results

\begin{tabular}{|c|c|}
\hline Variable & Composite Reliability \\
\hline Attitude $\left(\mathbf{X}_{1}\right)$ & 0.921 \\
\hline $\begin{array}{c}\text { Subjective Norm } \\
\left(\mathbf{Y}_{\mathbf{1}}\right)\end{array}$ & 0.903 \\
\hline $\begin{array}{c}\text { Perceived Behavior Control } \\
\left(\mathbf{Y}_{\mathbf{2}}\right)\end{array}$ & 0.941 \\
\hline Behavioral Interest $\left(\mathbf{Y}_{\mathbf{3}}\right)$ & 0.866 \\
\hline
\end{tabular}

The results of testing the outer model hypothesis for each variable can be seen in Table 8 . Based on Table 8 , all indicators had a p-value $<0.05$, therefore, it can be said that the research indicators can reflect each of the latent variables, namely behavior and attitudes, subjective norms, perceived behavioral control, and behavioral interest.

Table 8. Path Coefficient Value of the Variable with Indicators

\begin{tabular}{|c|c|c|c|}
\hline Variable & Indicator & $\begin{array}{l}\text { Loading } \\
\text { Value }\end{array}$ & p-value \\
\hline \multirow{3}{*}{ Attitude $\left(\mathbf{X}_{1}\right)$} & Cognitive Beliefs $\left(X_{1.1}\right)$ & 0.893 & $<0.001$ \\
\hline & $\begin{array}{c}\text { Affective Confidence } \\
\left(\mathbf{X}_{1.2}\right)\end{array}$ & 0.900 & $<0.001$ \\
\hline & Behavioral Belief $\left(X_{1.3}\right)$ & 0.884 & $<0.001$ \\
\hline \multirow{2}{*}{$\begin{array}{c}\text { Subjective } \\
\text { Norm } \\
\left(\mathbf{Y}_{1}\right)\end{array}$} & $\begin{array}{c}\text { Normatives Beliefs } \\
\left(Y_{1.1}\right)\end{array}$ & 0.908 & $<0.001$ \\
\hline & $\begin{array}{c}\text { Motivation to Comply } \\
\left(\mathrm{Y}_{1.2}\right)\end{array}$ & 0.908 & $<0.001$ \\
\hline \multirow{2}{*}{$\begin{array}{c}\text { Perceived } \\
\text { Behavior } \\
\text { Control } \\
\left(\mathbf{Y}_{2}\right) \\
\end{array}$} & Control Belief $\left(Y_{2.1}\right)$ & 0.943 & $<0.001$ \\
\hline & Perceived Power $\left(\mathbf{Y}_{2.2}\right)$ & 0.943 & $<0.001$ \\
\hline \multirow{3}{*}{$\begin{array}{c}\text { Behavioral } \\
\text { Interest }\left(\mathbf{Y}_{3}\right)\end{array}$} & $\begin{array}{c}\text { Positive Perception } \\
\left(\mathrm{Y}_{3.1}\right) \\
\end{array}$ & 0.784 & $<0.001$ \\
\hline & Desire $\left(\mathbf{Y}_{3.2}\right)$ & 0.829 & $<0.001$ \\
\hline & Recommendation( $\left(Y_{3.3}\right)$ & 0.864 & $<0.001$ \\
\hline
\end{tabular}


Hypothesis testing results on the inner model can be seen in Table 9. Based on Table 2, it was known that the relationship between behavior and attitudes on subjective norms, behavior and attitudes on behavioral control, subjective norms on behavioral interest, and perceived behavioral control on behavioral interest had a $\mathrm{p}$-value $\leq$ 0.01 , therefore, it can be concluded that the relationship between variables was proven to have significant influence. On the other hand, the relationship between behavior and attitudes on behavioral interest had a p-value $>0.10$, thus, it can be concluded that the relationship between variables in the model was insignificant or had no effect.

Table 9. Path Coefficient Value between Variables

\begin{tabular}{|c|c|c|c|}
\hline $\begin{array}{l}\text { Predictor } \\
\text { Variable }\end{array}$ & $\begin{array}{l}\text { Response } \\
\text { Variable }\end{array}$ & Path Coefficient & p-value \\
\hline \multirow{3}{*}{ Attitude $\left(\mathbf{X}_{1}\right)$} & $\begin{array}{l}\text { Subjective } \\
\text { Norm }\left(Y_{1}\right)\end{array}$ & 0.889 & $<0.001$ \\
\hline & $\begin{array}{c}\text { Perceived } \\
\text { Behavior } \\
\text { Control } \\
\left(Y_{2}\right) \\
\end{array}$ & 0.745 & $<0.001$ \\
\hline & $\begin{array}{c}\text { Behavioral } \\
\text { Interest }\left(\mathbf{Y}_{3}\right)\end{array}$ & 0.180 & 0.197 \\
\hline $\begin{array}{l}\text { Subjective } \\
\text { Norm }\left(Y_{1}\right) \\
\end{array}$ & $\begin{array}{c}\text { Behavioral } \\
\text { Interest }\left(\mathbf{Y}_{3}\right)\end{array}$ & 0.599 & 0.003 \\
\hline $\begin{array}{c}\text { Perceived } \\
\text { Behavior } \\
\text { Control } \\
\left(\mathrm{Y}_{2}\right)\end{array}$ & $\begin{array}{c}\text { Behavioral } \\
\text { Interest }\left(\mathrm{Y}_{3}\right)\end{array}$ & 0.440 & 0.002 \\
\hline
\end{tabular}

From Table 2, a path can be drawn based on the inner coefficient of the model in the following figure 4. In Figure 4, the relationship between behavior and attitudes and behavioral interests had no direct significant effect. However, an indirect relationship between the behavior and attitudes and behavioral interest was formed from two paths or through two mediating variables.

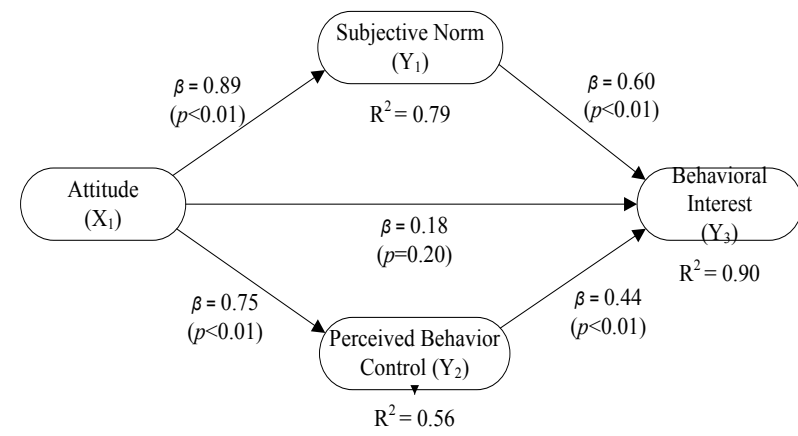

Figure 4. Path Diagram of Hypothesis Test Results

The results of the examination and testing of mediation variables using the Sobel test calculation are presented in Table 10. Based on Table 10, it was known that with a p-value of 0.004 , the effect of subjective norms and perceived behavioral control was proven to be a mediation of behavior and attitudes with behavioral interests. The value of the path coefficient of the subjective norms was greater than perceived behavioral control, consequently, it can be said that the mediating variable of subjective norms was better than the mediating variable of perceived behavioral control.

Table 10. Sobel Test Calculation Results

\begin{tabular}{|c|c|c|c|}
\hline $\begin{array}{c}\text { Mediation } \\
\text { Variable }\end{array}$ & $\begin{array}{c}\text { Path } \\
\text { Coefficient }\end{array}$ & Z-test & p-value \\
\hline $\begin{array}{c}\text { Subjective Norm } \\
\left(\mathbf{Y}_{\mathbf{1}}\right)\end{array}$ & 0.533 & 2.877 & 0.004 \\
\hline $\begin{array}{c}\text { Perceived Control } \\
\left(\mathbf{Y}_{\mathbf{2}}\right)\end{array}$ & 0.328 & 2.875 & 0.004 \\
\hline
\end{tabular}

\section{Conclusions}

Based on the results of SEM analysis with the WarpPLS approach, a direct effect of behavior and attitudes, subjective norms, and perceived behavioral control was obtained on the community's behavioral interest towards WANT-E products with a positive relationship between the variables of behavior and attitudes on subjective norms, behavior and attitudes on perceived behavioral control, subjective norms on behavioral interest, and perceived behavioral control on behavioral interest. Then the indirect effect as a total mediating variable with a positive relationship was found in the variables of behavior and attitudes on behavioral interest through subjective norms and behavior and attitudes on behavioral interest through perceived behavioral control. Accordingly, the good behavior and attitudes of the community towards WANT-E products by taking into account subjective norms and good perceived behavioral control of the community towards WANT-E products can increase the community's behavioral interest towards WANT-E products.

\section{REFERENCES}

[1] Ajzen, I. (1991). The Theory of Planned Behavior. Organizational Behavior and Human Decision Processes, 50(2), pp.179-211.

[2] Ariani, D., Yuki N. N. and Desi. (2017). Perbandingan Metode Bootstrap dan Jackknife Resampling dalam Menentukan Nilai Estimasi dan Interval Kontingensi Parameter Regresi. Jurnal Ekspoensial. Vol 8 Issue 1, pp. 43-49.

[3] Fernandes, A.A.R., Hutahayan, B., Solimun, Arisoesilaningsih, E., Yanti, I., Astuti, A.B., Nurjannah, \& Amaliana, L, (2019), Comparison of Curve Estimation of the Smoothing Spline Nonparametric Function Path Based on PLS and PWLS In Various Levels of Heteroscedasticity. IOP Conference Series: Materials Science and Engineering, Forthcoming Issue.

[4] Fernandes, A.A.R., Widiastuti, D.A., Nurjannah. (2020). Smoothing Spline Semiparametric Regression Model 
Assumption Using PWLS Approach. International Journal of Advanced Science and Technology. 29(4), pp. 2059-2070.

[5] Fishbein, M., and Ajzen. (1975). Belief, Attitude, Intention, and Behavior an Introduction to Theory and Research. London: Addison-Wesley Publishing Company.

[6] Hartono, J. (2007). Sistem Informasi Keperilakuan. ANDI: Yogyakarta.

[7] Hidayat, M.F., Fernandes, A.A.R., \& Solimun, (2019), Estimation of Truncated Spline Function in Nonparametric Path Analysis Based on Weighted Least Square (WLS), IOP Conference Series: Materials Science and Engineering, Forthcoming Issue.

[8] Iskandar, R., Mara, M. N. and Satyahadewi, N. (2013). Perbandingan Metode Bootstrap dan Jackknife dalam Menaksir Parameter Regresi untuk Mengatasi Multikolinieritas. Buletin Ilmiah Mat. Stat. dan terapannya (Bimaster). Vol 02 No 2, pp.137 - 146.

[9] Pratiwi, H. R. (2017). Pengujian Theory of Planned Behavior dan Motivasi terhadap Minat Mahasiswa Akuntansi Memperoleh Sertifikasi Chartered Accountant (Studi Kasus pada Mahasiswa Akuntansi Syariah IAIN Surakarta). Doctoral Dissertation: IAIN Surakarta.

[10] Rahmah. (2011). Pengaruh Sikap, Norma Subjektif, dan Perceived Behavior Control terhadap Intensi Membeli Buku Referensi Kuliah Ilegal pada Mahasiswa UIN Syarif Hidayaullah Jakarta. Program Studi Magister Fakultas Psikologi, UIN Syarif Hidayaullah: Jakarta.

[11] Riduwan, M. B. A. (2005). Skala Pengukuran Variabel-Variabel Penelitian. Bandung, ALFABETA.cv.

[12] Şahinler, S., and Topuz, D. (2007). Bootstrap and Jackknife Resampling Algorithms for Estimation of Regression Parameters. Journal of Applied Quantitative Methods. Vol. 2, No. 2, pp. 188-267.

[13] Saragih, S. A. (2008). Pembuatan dan Karakterisasi Karbon Aktif dari Batubara Riau sebagai Adsorben. Doctoral Dissertation, Universitas Indonesia: Jakarta.

[14] Setiawati, F.A., Mardapi, D. and Azwar, S. (2013). Penskalaan Teori Klasik Instrumen Multiple Intelligences Tipe Thurstone dan Likert. Jurnal Penelitian dan Evaluasi Pendidikan Tahun 17. 259-274.

[15] Setyawan, N. (2016). Analisis Faktor - Faktor yang Memengaruhi Niat menggunakan Kembali Aplikasi Mobile Berbasis Informasi: Studi Kasus Aplikasi ABC pada PT XYZ. Program Studi Magister Teknologi Informasi, Universitas Indonesia: Jakarta.

[16] Sholihin, M. and Ratmono, D. (2013). Analisis SEM-PLS dengan WarpPLS 3.0. Yogyakarta: ANDI Yogyakarta.

[17] Solimun. (2010). Metode Partial Least Square-PLS. CV Citra Malang: Malang.

[18] Solimun, Fernandes, A. A. R. and Nurjannah. (2017). Metode Statistika Multivariat: Pemodelan Persamaan structural (SEM) pendekatan WarpPLS. Malang: UB Press.

[19] Solimun. (2020). Warppls analysis application for effects of personality and commitment on the engagement of ngrebeg mekotek traditional actors in munggu village, bali,
International Journal of Advanced Science and Technology, 29(4), pp. 2025-2044.

[20] Tibshirani, R. J., and Efron, B. (1993). An Introduction to the Bootstrap. Monographs on Statistics and Applied Probability, pp. 57, 1-436. 